\title{
The Strategic Impact of Total Quality Management on Customer Satisfaction. A Case Study of Colour Fiesta Nigeria Limited
}

\author{
Gladys Harold-Juwah \\ Ph.D. in Management, Texila American University, Guyana
}

\begin{abstract}
The importance of Total Quality Management in businesses today cannot be over emphasised because the over-increasing needs of the customers and the right to quality has taken a long way in ensuring that organisational strategic objectives are set to meet this demand. Customer satisfaction is a major concern of most organisations, this has led to corporate strategies being considered as important in total quality management. This study examines the strategic impact of total quality management on customer satisfaction in Colour Fiesta Nigeria Limited which is involved in printing and publishing. The major aim of this study is to evaluate the relationship between senior management commitment in total quality management and the effect it will have on customer satisfaction. It is believed that customers are unsatisfied due to the failure of total quality management hence the active involvement of the top management. Based on the findings, it was revealed that the management of Colour Fiesta is more concerned of continuous quality improvement and customer focus philosophy than benchmarking, employee training, etc. There was also an inconsistency in integrating total quality management with the strategic planning process. In conclusion, the result shows that total quality management plays a vital role in the strategic implementation of customer satisfaction.
\end{abstract}

Keywords: Affinity and Ishikawa diagram, Benchmarking and QC Circle, ISO 9001 Standard, Process management, Quality function deployment, Total Quality.

\section{Introduction}

The basic element in this study are corporate strategies, total quality management and customer satisfaction. There is a need to understand the impact of the relationship between them and the effect on consumer behaviour.

Several attempts have been made by different researchers to study the concept of total quality management but ended up opening more gaps to be filled. Every Organisation inclusive of Colour Fiesta Nigeria Limited's aim is to make strategic decisions that will enable the company to earn profit through satisfying their customers.
Colour Fiesta Nigeria Limited is a printing and publishing organisation with a business operation in Nigeria. It has a staff strength of 200 (50 top management and 150 operational staff) and one of its main objectives is to be a leading printing firm that provides customers with top-notch quality in every first-time engagement with the company. It believes in continuous improvement through customer feedback, promoting employee and top management involvement, encouraging teamwork, flexible workforce, and developing strategies to improve quality and responsiveness in all sectors of the organization thereby achieving set goals and objectives, organizational sustainability, and returns on investment. 
It is a known belief that customers are regarded as king in the market and when they believe in a brand and are satisfied with the product and services offered by the organization, they become a good advocate and attract other prospective customers to the brand. Total Quality Management (TQM) is a continuous management approach that ensures the long-term goals and objectives of the organization are achieved through customer satisfaction. Every employee of the organization must be involved in improving the TQM processes, this will ensure that customer gets superior products and services when they are satisfied, which leads to customer loyalty, higher productivity that increases revenue, and reduction in waste.

The main aim of this research is to conduct a descriptive research design to verify the strategic impact of total quality management on customer satisfaction and this can be achieved by placing corporate strategy and total quality management in the context of consumer behaviour.

The study will develop an understanding of the relationship amongst the three key elements of this research as opposed to testing other existing theory. A literature review will be given as well as a description of the research methodology and the data collection method. The data will be reviewed and analysed on the reported relationship among organisational strategies, total quality management and customer satisfaction. Finally, the key findings and conclusion will be based on the analysis given.

\section{Objective of the Study}

It is believed that studying the impact of Total Quality Management on customer satisfaction is based on four focus areas which include, Customer Focus, process focus, innovation focus and environmental focus, these focuses will enhance organizational performance. In this study, we are focusing on a single focus area - customer focus. The major objective is to identify the strategic impact of the relationship between TQM and performance through customer satisfaction.

\section{Literature Review}

\section{Total Quality Management Concept}

Total Quality Management (TQM) is a management approach which focuses on quality, processes and people with major enhances on improving organisational performance and satisfying customers [1]. Quality is no longer considered as the duty of the quality assurance team but everyone's job in the organisation. Quality improvement has become a way of life as well as a philosophy. [2] supports this view that company-wide philosophy requires all employees at all levels to focus on improving each business process of the organisation. In this vein, the more processes are improved in every department in Colour Fiesta, the easier it is to deliver higher quality products and services to customers.

TQM is applicable to every organisation irrespective of size and motives. The emphasis on quality in all facets of an organisation like Colour Fiesta will assist to reduce waste and rework and increase production efficiency. TQM improves the relationship between existing process and customer satisfaction by integrating management systems. It also allows for the implementation and monitoring of other tools like ISO and Ishikawa diagram, values (continuous improvement, customer, and process focus), and methodologies (benchmarking, QC Circles), all these varies from one organisation to the other. 


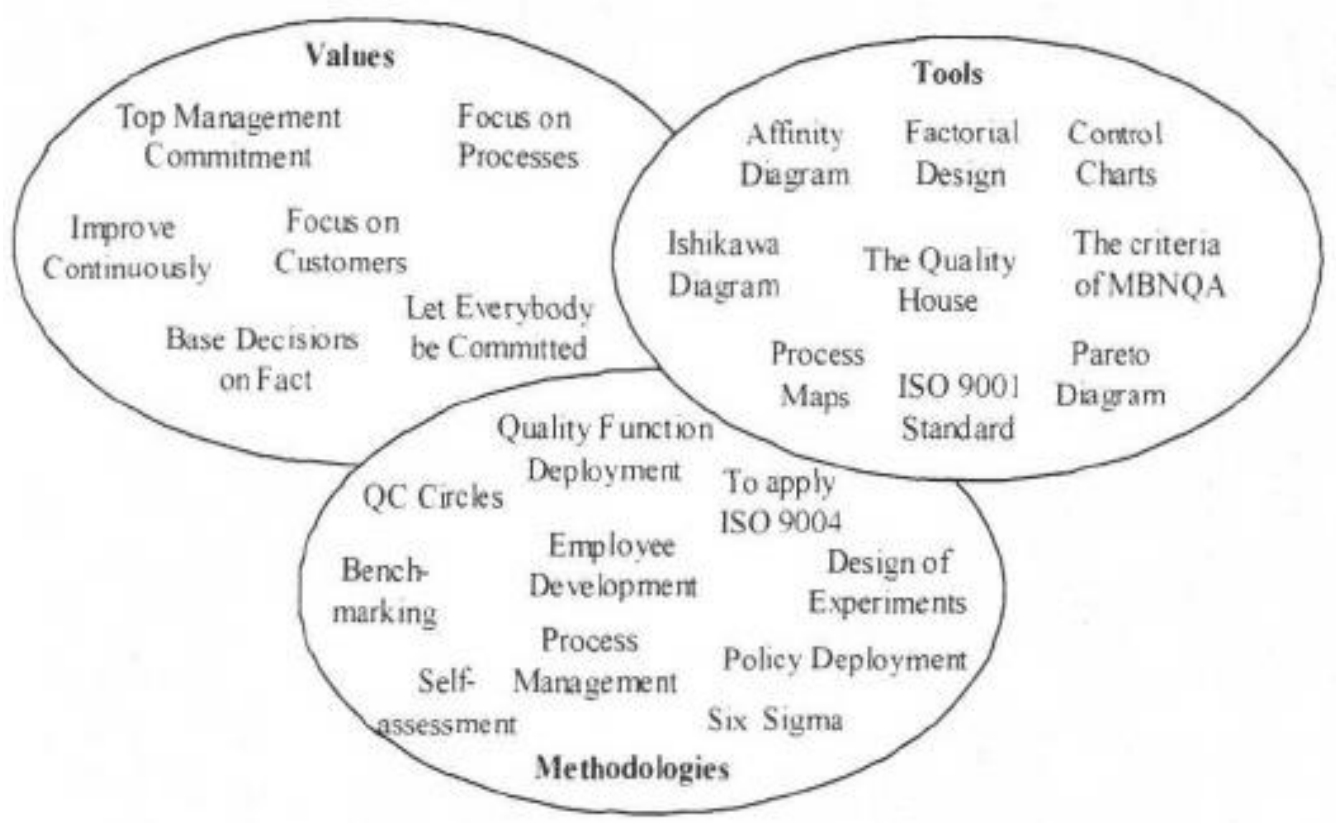

Figure 1. TQM as a Management System of Values, Tools and Methodologies

Source: Hellsten, U. and Klefsjo, B [3]

\section{Customer Satisfaction}

Customer satisfaction measures how well an organisation's product and services meet or surpasses the customer's expectation. When a customer is satisfied, he/she contributes to the long-term relationship development and construction of loyalty. This loyalty makes the organisation to have a competitive edge over other organisation, thereby increasing return on investment. [4] opined that Loyalty is dependent on the degree of customer satisfaction and trust.

When a company has loyal customers, it will gain positive word-of-mouth marketing which is highly effective and free. It is observed that customer satisfaction ratings have a powerful effect on an organisation most especially in printing and publishing, so employees focus on fulfilling customer's expectations. When there is a dip in these ratings, it shows there is a problem that can affect service and profitability. More so, it is very important for companies to set strategies that can effectively manage customer satisfaction through the inclusion of TQM.

\section{Benefit of Total Quality Management}

There are numerous benefits and goals of total quality, it helps in the reduction of total quality costs through prevention of defective products than at the expense of quality failure cost. [5] stated that total quality lowers costs, gives higher revenue, satisfies customers, and empowers employees.

Secondly, TQM assists in increasing productivity as a result of cost reduction, highend technology and resources, infrastructure, and competent employees. In addition, TQM enables organisation to conduct research on prevailing challenges and bring in innovative marketing decisions which attract customers. TQM focuses on customer satisfaction because it creates a pathway to understand the needs of the customers which enables the organization to deliver specific products and services. [6] opined that customers' needs should be integrated in the design and development of products, in so doing, customers will be treated as an equal partner in the life cycle of the product. 
Furthermore, TQM brings about changes in the behavioural pattern of the workers by promoting good work culture, teamwork, selfdevelopment, and employee engagement which enables better organizational performance. It is obvious that TQM brings both tangible (high product quality, increased profitability, and market share) and intangible returns (teamwork, better communication, goodwill, and employee engagement). It also expects employees to undergo substantial training, participate in quality improvement and organizational wide involvement. Everyone in the organisational hierarchy must partake and strongly support the success of the TQM program.

\section{TQM and Organizational Performance and Sustainability}

Total Quality Management should be made more prominent within the purview of corporate strategic processes. Senior management should be involved in the creation of corporate image and driving campaign for new programme change and continuous improvement.

The growing awareness of TQM ensures that business drivers are linked with organisational issues such as strategic quality planning, leadership, people, and process management.

TQM is seen as a management system that includes a component of sustainable development. It must be used to establish objectives and strategies that will aid in meeting stakeholder's requirements.

It should monitor the external environment and the organisational capabilities as well as provide the feedback needed for continuous improvement, innovation, and identification of the desired organisational changes. TQM implementation brings a positive impact on the quality of the product and services, thereafter, having a better effect on the overall performance of the organisation. [7] stated that employee commitment, customer focus, shared vision does not necessarily contribute to a higher quality outcome. On the contrarily, I believe that the importance of total quality management in increasing organisational performance should not be ignored because its benefit outweighs its failure.

\section{Obstacles affecting effective TQM}

There are different obstacles and barriers affecting the successful of total quality management and this includes lack of leader for quality, lack of planning, inadequate human resources, and lack of customer focus.

The main reason TQM fails is due to half measures in implementing TQM. Some organisations are not willing to commence the total cultural transformation, this is because some senior managements do not know what cultural change is and the best way to approach the transformation. In continuation, top management's failure to move employees towards a total quality concept leads to one of the obstacles against the success of TQM. Total quality management fails due to improper implementation and not the TQM theories and methods [8].

The management's lack of capacity to identify and close up the gaps between TQM and the actual practise, that is, the inquiry process, analysis, and embedded actions are the major causes of TQM implementation failure. Lack of senior management commitment is an important obstacle that should be avoided, so training of top management should be carried out to enable them to understand the benefits and philosophy of TQM and the best way to implement it.

\section{Research Methodology}

\section{Data Collection and Sample}

The purpose of this study is to investigate the strategic impact of Total Quality Management on customer satisfaction in Colour Fiesta Nigeria Limited. A descriptive research design and inferential statistical techniques were used for this study. The description research design determines the relationship between the variables and identifies the effect of one 
variable on the others. Primary and secondary data sources were used for analysing this study. The primary data was obtained through the use of a questionnaire while the secondary data were through related literature collected from published and unpublished sources.

Two different questionnaires were administered, one was applied to customers and the second questionnaire was given to the employees of the printing and publishing company. The respondents were asked to use the 5 points Likert-scale (from 1 being poor to 5 very good) to indicate their level of agreement.

A total of 100 questionnaires were administered to customers and employees of Colour Fiesta Nigeria Limited. Eighty of the questionnaires were successfully retrieved which constitutes $80 \%$ of the response rate of which $40(50 \%)$ were filled by females and 40 $(50 \%)$ by males. The sample age group is between 17 and 65 years old with an average age of 32 years.

\section{Test of Reliability}

The questionnaire was subjected to a reliability test using The Cronbach Alpha approach and obtained a reliability co-efficient of 0.774 . It can be said that a reliability of 0.7 and above on a significant sample is considered a good instrument [9] hence the obtained value is internally acceptable as consistent among the variables.

\section{Data Presentation and Analysis}

The collated data was analysed using descriptive and inferential statistical techniques. The second hypothesis was analysed using descriptive statistics to describe the demographic characteristics of the respondents while the first hypothesis at 0.05 alpha level used the simple regression analysis. The missing values were checked before the statistical analysis was carried out. There are different number of items in each domain hence a normalisation procedure was applied. The sum of raw scores in each domain was divided by the number of items in the domain using the Likert Scale of $0-5$ scales for each domain for normalisation.

The description statistic which was used to obtain the primary source of data for demographics is shown in the table below.

Table 1. Respondents' Response to the Questionnaire

\begin{tabular}{|l|l|l|}
\hline Criteria & Frequency & Percentage Response \\
\hline Gender & 40 & 50 \\
\hline Male & 40 & 50 \\
\hline Female & \multicolumn{2}{l|}{} \\
\hline Educational qualification & \multicolumn{2}{l|}{} \\
\hline Senior Secondary certificate & 12 & 15 \\
\hline National Diploma & 22 & 27.5 \\
\hline Degree & 30 & 37.5 \\
\hline Higher qualification & 16 & 20 \\
\hline Age & \multicolumn{2}{|l}{} \\
\hline $20-25$ & 11 & 13.8 \\
\hline $25-35$ years & 33 & 41.2 \\
\hline 35 years and above & 36 & 45 \\
\hline Level of Patronage & \multicolumn{2}{|l}{} \\
\hline Low & 15 & 18.8 \\
\hline Moderate & 47 & 58.8 \\
\hline High & 18 & 22.5 \\
\hline
\end{tabular}


Table 2. Summarised Multiple Regression Analysis of the Result of the Strategic Relationship between Total Quality Management and Customer Satisfaction

\begin{tabular}{|l|l|l|}
\hline Variable & Co-efficient & Probability \\
\hline Employee's attitude & 0.23 & 0.07 \\
\hline Focus on material resources & -0.06 & 0.63 \\
\hline Leadership and management commitment & 1.40 & 0.17 \\
\hline Continuous improvement & 0.38 & $0.00 *$ \\
\hline Effective communication & -0.09 & 0.50 \\
\hline Adequate knowledge & 0.00 & 0.99 \\
\hline Prompt quality delivery & 0.35 & $0.00 *$ \\
\hline
\end{tabular}

Table 3. Regression Analysis of the Data

\begin{tabular}{|l|l|}
\hline$R$ & 0.59 \\
\hline$R^{2}$ & 0.35 \\
\hline Durbin-Watson & 1.69 \\
\hline$F$ - statistics & 4.10 \\
\hline
\end{tabular}

Table 4. Ranking and Mean Analysis of External Factors that Impact TQM as Stated by the Respondents

\begin{tabular}{|l|l|l|}
\hline External Factors & Means & Rank \\
\hline Lack of management commitment & 3.59 & $1^{\text {st }}$ \\
\hline Poor employees training & 3.56 & $2^{\text {nd }}$ \\
\hline Poor communication & 3.55 & $3^{\text {rd }}$ \\
\hline Lack of employee feedback & 3.17 & $4^{\text {th }}$ \\
\hline Bureaucratic approach & 2.65 & $5^{\text {th }}$ \\
\hline
\end{tabular}

\section{Result and Discussion}

As shown in Table 1, the questionnaire was distributed equally with $50 \%$ of respondents from male and female respectively. In addition, it shows the respondents understood the content of the questionnaire as $85 \%$ of the respondents has above the senior school certificate. $86.2 \%$ of the respondent are adults since they are above 18 years old hence are mature enough to know what quality entails. Furthermore, in the level of patronage, $81.3 \%$ show that they have a middle to a high level of patronage of the printing and publishing company, hence having a good knowledge of the required response to provide.

From the regression analysis shown in Table 3 , the obtained result showed that $35 \%$ of the variation in the dependent variables is seen in the explanatory variable. The probability of rejecting the F- statistics (4.10) was seen to be
0.00 which shows there is a significant relationship between the independent variable and the dependent variable. 1.69 which is the Durbin Watson statistic is within the acceptable range, it shows that auto serial correction is not present. The variables that are most visible in the printing and publishing company's survey are continuous improvement and prompt service delivery which have a positive coefficient of 0.38 and 0.35 respectively.

There is a positive but insignificant relationship between total quality management and all the independent variables in the regression analysis. This indicates that other factors have an impact on customer satisfaction apart from the quality provided by the organisation. According to [10] the percentage of satisfied migrated customers is even higher. [11] also stipulated that there is no significant relationship between transaction satisfaction appraisal and the length of the company- 
customer relationship. [12] disagrees with this assertion by stating that customer satisfaction and customer loyalty are closely linked. In my opinion, customer satisfaction is not only dependent on total quality practices but also on other factors like closeness of the organisation, alternatives availability, external influences, and social status.

As shown in Table 4, it indicates that there is a lack of management commitment and appreciation of the strategic impact of TQM on customer satisfaction. This is evident in Colour Fiesta Nigeria Limited. When the further probe was done in seeing TQM in a strategic context, most of the response was "TQM comes like a flash and there is a commitment to quality and things are continuously improving". This comment does not provide a TQM as a strategic driver in the organization, hence in agreement with the respondents, the organization do not see TQM as a key strategic driver.

The other factor that affected TQM is lack of proper training of the employees on TQM concept and its invariable impact on customer satisfaction. The organization should provide useful training for the existing staff and employ more skilled workers to gain more satisfied customers.

Furthermore, poor communication has a negative impact in the strategic decision of the organization. For the success of TQM, all members, suppliers, and customers must communicate effectively because communication acts as a vital link in the element of TQM.

In addition, there was a notable lack of employees input and feedback to the corporate level. The employees are allowed to provide their input in the decision-making process on already established goals and targets and this is placed upon each unit to be achieved operationally. The organization should improve its feedback collection system.

Lastly, Colour Fiesta has a top-downbureaucratic and rigid strategic form. All the corporate strategies are created by the CEO and the senior management. There is little evidence of dynamic structure that can create a fastmoving strategic process that can ensure customers are satisfied and lead to customer loyalty.

\section{Conclusion}

This research attempted to answer the strategic impact of implementing TQM and its effect on customer satisfaction. The description and inferential statistics were used to determine a picture of TQM, its influence on strategies, and customer satisfaction. The data revealed a series of key issues. First, the inconsistency in TQM in the organisation was researched hence there is a need to integrate TQM and strategy with the company, so necessary progress can be made in achieving customer satisfaction.

Secondly, TQM should be made the key driver during the strategic decision-making process because in the organization there is little evidence of intertwine of TQM and corporate strategy. More so, employee involvement, feedback mechanism, and customer impact should be directly attributed to TQM, so it can have little impact on strategic decision making.

Furthermore, the study analysed relevant data on TQM and customer satisfaction which revealed that TQM has a relative low impact on the operations of Colour Fiesta and customer satisfaction. It is also noted that external influences limit the operation of total quality management and customer focus in the organization. Based on the findings, we can conclude that if Colour Fiesta Nigeria Limited successfully set strategies that adopt quality management practices, it will have positive impact on customer satisfaction level. In addition, focusing on customers enhances business performance.

\section{Acknowledgement}

I would like to convey my heartfelt appreciation and love to my husband Harold Juwah who has constantly proofread this 
project, his unconditional support, and inspiration in every step of this study. My appreciation also goes to the staff and management of Colour Fiesta Nigeria Limited that gave their unreserved assistance in the survey that brought this project to a reality.

\section{References}

[1] Davies, E., 2003, Quality: Its historical context. Engineering Management pp. 14-17.

[2] Mehra, S., Hoffman, J. and Sirias, D., 2001, TQM a management strategy for the next millennia. International Journal of Operations and Production Management. 21(5/6) pp. 855-876, https://www.researchgate.net/.

[3] Hellsten,U. and Klefsjo, B., 2000, TQM as a management system consisting of techniques, values, and tools. pp 238-244.

[4] Seto-Pamies, D., 2012, Customer loyalty to service provider. Total Quality Management \& Business Excellence. pp. 1257-1271.

[5] Johnson, R., 2001, Linking Complaint Management to Profit. International Journal of Service Industry Management, vol 12(1) pp 60 - 69, https://docplayer.net/.

[6] Goldman, H., 2005, The origins and development of quality initiative in American business, The TQM Magazine. Vol. 17, No. 3, pp 217-25.

[7] Dow, D., Samson, D. and Ford, S., 1999 , Exploding the myth: Do all quality management practices contribute to superior quality performance. Production and Operations Management 8, 1-27.

[8] Beer, M., 2003, The role of management quality and implications for leading a total quality management transformation. Decision sciences pp 623-642

[9] Ritter, N., 2010, Understanding a widely misunderstood statistic. Cronbach's alpha. Southwestern Educational Research Association. 17(9), 167-175.

\section{Conflict of Interest Statement}

I declare that there is no conflict of interest in this study.

[10]Reichheld, F., 1993, Loyalty Based Management. Harvard Business Review. 71(2) pp 64-73.

[11]Bolton, R., 1995, Linking customer satisfaction to the duration of customer provider relationships and revenues. Waltham, MA. GTE Laboratories.

[12]Fornell, G., 1992, A national customer satisfaction barometer. The Swedish experience. Journal of Marketing 56, pp 1-18, http://www.sciepub.com.

[13]Boshoff, C., 1997, An Experimental study of Service recovery options. International Journal of Service Industry Management, vol 8(2) pp. 110 130, https://www.researchgate.net/.

[14] Campbell, A. and Yeung, S., 1991, Creating a sense of mission. Long Range Planning. pp 17 - 24.

[15]Crosby, B., 1979, Quality is Free, Mentor, McGraw-Hill Book Company, New York.

[16]Huband, E., 1992, Developing effective management skills. Management Accounting, vol 74, pp 44-47.

[17] Kanji, G., 1998, Measurement of Business Excellence, Total Quality Management, Abingdon, Chapman \& Hall.

[18]Levy, P., 2003, Industrial/Organisational Psychology. Understanding the Workplace. Houston Mifflin, Boston, MA

[19] Schein, L., 1991, Communicating Quality in the Service Sector, The Conference Board, New York.

[20] Schein, E., 1992, Organisational Culture and Leadership, $2^{\text {nd }}$ edition, Jossey-Bass, San Francisco. [21]Texila American University, 2021, Total Quality Management. Retrieved June 10, 2021, https://dblplms.tauedu.org. 